\title{
CT Guided FNAC of lung mass - A retrospective study of Disease Spectrum
}

\author{
Singh $\mathbf{R}^{1}$, Mallik $\mathbf{M}^{2}$, Rai H. $\mathbf{K}^{3}$, Singh $\mathrm{S}^{4}$, Mallick $\mathrm{S}^{5}$, Manish Kumar ${ }^{6}$ \\ ${ }^{1}$ Dr. Rashmi Singh, Assistant Professor, Pathology, Patna Medical College, ${ }^{2}$ Dr. Mahasweta Mallik, Assistant Professor, \\ Pathology, Patna Medical College, ${ }^{3}$ Dr. Hari Kishore Rai, Consultant Radiologist, Max Life, Patna, ${ }^{4}$ Dr. Shweta Singh \\ Tutor, Microbiology, AIIMS, Patna, ${ }^{5}$ Dr. Sujata Mallick, Assistant Professor, Pathology, KPC Medical College, \\ Jadavpur, ${ }^{6}$ Dr. Manish Kumar, Assistant Professor, Pathology, Patna Medical College, Bihar, India
}

Address for correspondence: Dr. Mahasweta Mallik, Email: coolsama6773@yahoo.co.in

\begin{abstract}
CT guided FNAC is a well established method in the cytological diagnosis of pulmonary lesion. Aim: Aim of our study is to evaluate the pathological spectrum of disease in lump through CT guided FNAC. Material \& method: 69 causes were evaluated retrospectively for a period of 4 yrs. Result: out of 69 cases $52.1 \%$ were male. Mean age was 54 . 34 years. $65.2 \%$ having malignant lesion \& 34.7\% have benign. Adeno CA was the predominant malignant tumour. Conclusion: CT guided FNAC can diagnose pulmonary lesion fairly accurately leading to less morbidity \& mortality as treatment can be started early.
\end{abstract}

Key words: Computed tomography, Fine needle aspiration cytology, Lung mass

\section{Introduction}

Computed tomography guided fine needle aspiration cytology is a well established method in the cytological diagnosis of pulmonary nodules, FNAC distinguishes between benign \& malignant lesion \& also helps in typing of cancer so specific therapy such as chemotherapy or surgery can be started without delay, FNAC was first used by martin \& ellis [1] as a diagnostic tool. In 1976 Haaga \& Alfidi reported CT guided biopsy \& since then this procedure has be shown to be both effective \& accurate. The diagnostic accuracy is reported to be more than $80 \%$ in benign disease \& more than $90 \%$ in malignant disease [2] pneumothorax is the most common complication. Authors have reported 22-45\% risk of pneumo-thorax in CT guided FNAC, The purpose of this study is to evaluate the pathological spectrum of disease in lungs through $\mathrm{CT}$ guided FNAC [3].

\section{Material \& Method}

The study was carried out in a tertiary care teaching institute in patna $\&$ a nearby diagnostic centre. A total

Manuscript received $25^{\text {th }}$ April 2016

Reviewed: $11^{\text {th }}$ May 2016

Author Corrected: $24^{\text {th }}$ May 2016

Accepted for Publication $5^{\text {th }}$ June 2016 of 69 cases were studied for a period of 4 yrs from Jan 2011 to Dec 2014. Exclusion criteria were COPD, bleeding disorder, pulmonary arterial HTN \& uncooperative patient.

Selection criteria were: Co-operative patient who were able to hold breath. CT guided FNAC was performed by pathologist in co-oradination with radiologist as OPD procedure, to each patient risk \& benefit were explained \& informed consent taken. Skin was cleaned by betadine \& $21 \mathrm{G}$ - $88 \mathrm{~mm}$ long spinal needle was introduced through percutaneous transthoracic approach. The exact position of lesion was established by CT scan \& the measurement of site, angle, depth, route of needle was determined. After the needle placement \& CT scan done to ascertain that the tip of the needle was within the mass.

The aspirate was obtained by to \& fro movement of needle within the mass. Air dried smears were stained with MGG stain, Alcohol fixed smear were pap stained $\&$ the evaluation was done. Patients were kept for $2 \mathrm{hrs}$ under observation. In our study 2 cases developed pneumo-thorax who were managed conservatively. 3 had chest pain \& had mild haemorrhage from the lesion area. All were managed conservatively. 


\section{Result}

Out of 69 cases 36 were male \& 33 female.

Age group was from 27 to 84 years with mean age of 54.34yrs.

Table 1: Showing spectrum of lesion

\begin{tabular}{|c|c|c|}
\hline Disease & No of cases & $\%$ \\
\hline Sq cell CA & 17 & 24.6 \\
\hline Adeno CA & 23 & 33.33 \\
\hline Small cell CA & 2 & 2.89 \\
\hline Poorly diff CA & 3 & 4.34 \\
\hline Pyogenic Abscess & 5 & 7.24 \\
\hline Ch. Non Sp.Infl. & 13 & 18.84 \\
\hline TB & 4 & 5.7 \\
\hline Benign Cystic & 1 & 1.44 \\
\hline Keratinising Cyst & 1 & 1.44 \\
\hline
\end{tabular}

24 cases were of benign lesion. Among the benign lesion ch. non sp in flammation was the most common, accounting for 13 cases followed by pyogenic abscess which were 5cases, tuberculosis 4 cases \& Benign cystic disease \& keratinising cyst 1 case each.

45 cases were malignant with adeno CA exceeding sq cell CA, 23 \& 17 respectively. Poorly differentiated CA was 3 and small cell CA 2 cases.

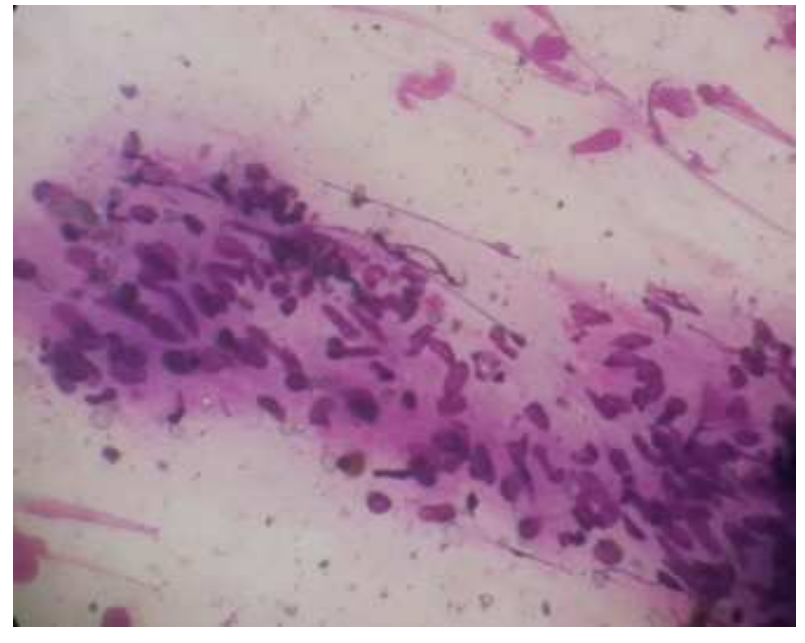

Fig 1: showing tuberculous granuloma in lung. (MGG stains 400X).

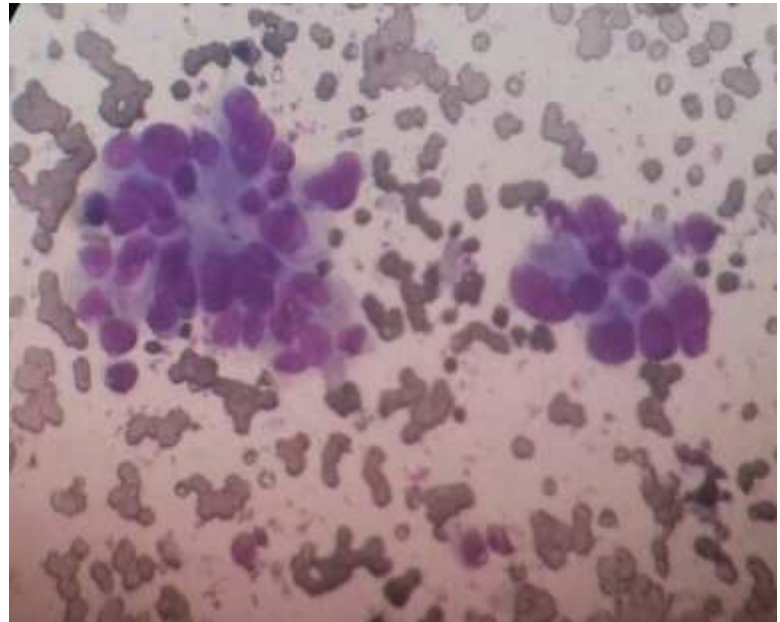

Fig 2: showing adenocarcinoma of lung. (MGG stains 400X).

\section{Discussion}

CT guided transthoracic needle aspiration cytology is safe \& accurate method for diagnosis \& categorization of malignant $\&$ benign lesion. Accuracy of procedure varies in range from $64 \%$ to $97 \%$ [3]. Our present study 69 cases were studied over a period of 4 yrs. Conclusive cytodiagnosis diagnosis were made in all the 69 cases. Most Patients tolerated the procedure well. Most common complaint was pain at the procedure site which subsided without medicine in 4-6 hrs. 2 cases had pneumothorax which was mild \& resolved conservatively. No chest tube insertion was necessary. 2 cases had mild hemorrhage where no treatment was required. 
All the cases were adult. The mean age was 54.34 yrs similar to other studies. Mondal et al has a mean age of 56.6 yrs [4], Singh et all [5] 56.4 yrs was the average age and Saha et al 56.8 yrs [6].

There was a male preponderance [52.1\%]. Percentage of male in other studies were Tan et al 71.1\% [7], Saha A et al [6] $78.9 \%$, Bandyopadhyay et al 80.6\% [8] \& Mondal et at $64.51 \%$ [4]. Out of the 69 cases $24(34.7 \%)$ were benign \& 45 (65.2\%) were malignant. Mondal et al had benign lesion $8.07 \%$ and malignant lesion 91.93\%.[4]. Tan et al had 65.8\% malignant, $1.8 \%$ atypical and $25.4 \%$ benign and $7 \%$ inadequate [7].

The incidence of Adenocarcinoma was higher than squamous cell carcinoma in our study similar to study by Mondal et at [4], Tan et al [7] \& Madan et al [9]. Mondal et al had adenocarcinoma in $51.72 \%$ followed by squamous cell carcinoma $22.41 \%$.[4]. Other National \& international studies showed squamous cell CA to be more than adenocarcinoma $[8,10,11,12]$.

Table comparing result of CT guided FNAC with other studies.

\begin{tabular}{|c|c|c|c|c|}
\hline studies & No. of Cases & $\begin{array}{c}\text { Pneumothorax } \\
\text { Complication }\end{array}$ & Hemorrhage & Haemoptysis \\
\hline Stanley et al (1987) [13] & 458 & $133(29 \%)$ & - & $5(1.1 \%)$ \\
\hline Vansonmen berge et al (1988) [14] & 150 & $64(42.7 \%)$ & 2 & $5(3.3 \%)$ \\
\hline Haramati et al (1995) [15] & 32 & $3(9.4 \%)$ & - & - \\
\hline Santambrogio et al (1997) [16] & 110 & $23(20.9 \%)$ & - & - \\
\hline Gouliamos et al (2000) [17] & 110 & $2(3.1 \%)$ & 1 & $10(5.4 \%)$ \\
\hline Mohammad et al (2001) [4] & 184 & $2(1.1 \%)$ & - & - \\
\hline Gupta et al (2002) [18] & 37 & $1(2.7 \%)$ & 1 & $1(2.9 \%)$ \\
\hline Singh et al (2004) [5] & 34 & $4(11.8 \%)$ & 4 & - \\
\hline Mondal et al (2013) [4] & 130 & & 2 & - \\
\hline Present (2016) & 69 & $2(2.8 \%)$ & & - \\
\hline
\end{tabular}

A study by Kalhan S et al showed sensitivity and specificity of CT guided FNAC to be $93.2 \%$ and $100 \%$ respectively. (20). USG guided FNAC sensitivity and specificity was $91.3 \%$ and $100 \%$ respectively. (20). Both seems to be good method for diagnosis of lung lesion.

\section{Conclusion}

We conclude then due to the high sensitivity \& specificity CT guided FNAC of lung mass gives early diagnosis \& improve treatment modality reducing morbidity \& mortality due to disease. Complication due to this procedure is not high \& can be managed conservatively.

Funding: Nil, Conflict of interest: None initiated. Permission from IRB: Yes

\section{References}

1. Martin HE, Ellis EB. BIOPSY BY NEEDLE PUNCTURE AND ASPIRATION. Ann Surg. 1930 Aug;92(2):169-81.
2. Geraghty PR, Kee ST, Mc Farlane G, Razavi MK, Sze DY, Dake MD. CT-guided transthoracic needle aspiration biopsy of pulmonary nodules: needle size and pneumothorax rate. Radiology.2003 Nov;229(2):475-81.

3. Herman PG, Hessel SJ. The diagnostic accuracy and complications of closed lung biopsies. Radiology. 1977 Oct;125(1):11-4.

4. Mohammad GM. CT guided fine needle aspiration cytology in the diagnosis of thoracic lesions. JIMA 2001:99(10):1-5.

5. Mondal SK, Nag D, Das R, Mandal PK, Biswas PK, Osta M. Computed tomogram guided fine-needle aspiration cytology of lung mass with histological 
correlation : A study in Eastern India. South Asian J Cancer. 2013 Jan;2(1):14-8. doi: 10.4103/2278-330X. 105881 .

6. Singh JP, Garg L, Setia V, Computed tomography guided fine needle aspiration cytology in difficult thoracic mass lesions-not approchable by USG. Indian J radiology. Imaging 2004 May:14:395-400.

7. Saha A, Kumar K, Choudhuri MK. Computed tomography-guided fine needle aspiration cytology of thoracic mass lesions: A study of 57 cases. J Cytol. 2009 Apr;26(2):55-9. doi: 10.4103/0970-9371.55222.

8. Tan KB, Thamboo TP, Wang SC, Nilsson B, Rajwanshi A, Salto-Tellez M. Audit of transthoracic fine needle aspiration of the lung : cytological subclassification of bronchogenic carcinomas and diagnosis of tuberculosis. Singapore Med J. 2002 Nov; 43(11):570-5.

9. Bandyo padhyay A, Laha R, Das TK et al. CT guided fine needle aspiration cytology of thoracic mass lesions: A prospective study of immediate cytological evaluation : Indian J pathological Microbiology. 2007 Jan; 50(1) : 51-5

10. Madan M. Bannur Evaluation of FNAC in lung disease. Turk J pathology. 2010 Nov; 26(1): 1-6.

11. Shah S, Shukla K, Patel P. Role of fine needle aspiration cytology in diagnosis of lung tumours-a study of 100 cases. Indian J Pathol Microbiol. 2007 Jan; 50(1):56-8.

12. Jaya SE, Pavani B, Chandra E et al. Computed tomography guided percutaneous thoracic: Fine needle aspiration cytology in lung \& mediastinum. J Cytol Histol. 2010; 107:1-3 doi:4172/2157-7099.1000107.

13. Basnet SB, Thapa GB, Shahi R, Shrestha M, Panth R. Computed tomography guided percutaneous transthoracic fine needle aspiration cytology in chest masses. JNMA J Nepal Med Assoc. 2008 Jul-Sep; 47(171):123-7.

14. Stanley JH, Fish GD, Andriole JG, Gobien RP, Betsill WL, Laden SA, Schabel SI. Lung lesions: cytologic diagnosis by fine-needle biopsy. Radiology. 1987 Feb;162(2):389-91.

15. vanSonnenberg E, Casola G, Ho M, Neff CC, Varney RR, Wittich GR, Christensen R, Friedman PJ. Difficult thoracic lesions: CT-guided biopsy experience in 150 cases. Radiology. 1988 May;167(2):457-61.

16. Haramati LB. CT-guided automated needle biopsy of the chest. AJR Am J Roentgenol. 1995 Jul; 165 (1):53-5.

17. Santambrogio L, Nosotti M, Bellauiti N et al. CT guided FNAC of solitary pulmonary nodules: a prospective randomised study of immediate cytologic evaluation. Chest 1997 Aug; 112:423-5 doi:10. 1378 / chest.112.2.423.

18. Gouliamos AD, Giannopoulos DH, Panagi GM, Fletoridis NK, Deligeorgi-Politi HA, Vlahos LJ. Computed tomography-guided fine needle aspiration of peripheral lung opacities. An initial diagnostic procedure? Acta Cytol. 2000 May-Jun;44(3):344-8.

19. Gupta S, Wallace MJ, Morello FA Jr, Ahrar K, Hicks ME. CT-guided percutaneous needle biopsy of intrathoracic lesions by using the transsternal approach: experience in 37 patients. Radiology. 2002 Jan; 222 (1) : 57-62.

20.Kalhan S, Sharma P, Sharma S, Dudani S, Ramakrishnan Ts, Chowdhry A. Evaluation of precision of guidance techniques in image guided fine needle aspiration cytology of thoracic mass lesions. J Cytol. 2012 Jan;29(1):6-10. doi: 10.4103/0970-9371.93209.

\section{How to cite this article?}

Singh R, Mallik M, Rai H. K, Singh S, Mallick S, Manish Kumar. CT Guided FNAC of lung mass - A retrospective study of Disease Spectrum. Int J Med Res Rev 2016;4 (7):1088-1091.doi: 10.17511/ijmrr.2016.i07.02. 